\title{
Oncology at general hospital of Mexico. Its origins
}

\author{
Alfonso Torres-Lobatón * \\ Oncology Service, Hospital General de México "Dr. Eduardo Liceaga”, Mexico City, Mexico
}

\begin{abstract}
Objective: The objective of the study was to carry out a review of the birth and evolution of Oncology at the General Hospital of México (GHM), cradle of Oncology in our country. Background: In 1922, GHM acquired 50 mg of radiobromide, which begins the fight against cancer in Mexico. In 1937, the Oncology Unit (OU) was inaugurated in pavilion 13 and Dr. Ignacio Millán was the first head of service. A decade later, with radiotherapy oncologists Dr. Guillermo Montaño Islas and Dr. José Noriega Limón, surgery oncologists Dr. José Manuel Velasco Arce and Dr. Horacio Zalce Torres, and pathologist Dr. José de Jesús Curiel, the OU becomes the first center dedicated to the treatment of cancer patients and the first Human Resources Training Institution for this purpose. Evolution: Dr. Montaño and Dr. Rodolfo Díaz Perchez restructure the Radiotherapy Unit and create the Oncology University Specialty. Dr. Héctor Rodríguez Cuevas joined the Service and consolidated the cancer surgery school. Dr. Irma Nora Hidalgo and Dr. Raquel Gerson Cwilich were members of the first generation of clinical oncologists in the OU. Since 2011, comprehensive care for cancer patients has been carried out in a modern building equipped for this purpose. Conclusions: The GHM begins the diagnostic and therapeutic approach for cancer patients in Mexico. Comprehensive care is, currently, carried out in the latest state-of-the-art facilities.
\end{abstract}

Key words: Oncology. Origins. Evolution. Mexico.

\section{Introduction}

The diagnostic and therapeutic approach to neoplasms has been the subject of spectacular progress over the course of this century, based on studies of tumor markers from blood samples, and/or by immunohistochemical studies of neoplastic tissues and molecular biology. This has allowed for the implementation of target therapies, as well as imaging studies to evaluate the behavior of neoplasms such as positron emission tomography scans, to name but a few. It is relevant to try to explore how the study and management of cancer came about in our country.

The Mexican Society of Oncology states that this specialty was born in the General Hospital of Mexico, but to talk about the history of Oncology in that Institution represents a formidable challenge due to the lack of documentation. What will be described below was extracted from data obtained from some available accounts of that time, from some publications made by the teachers who introduced and applied the knowledge acquired abroad in this hospital and from experiential situations of the author.

\section{History}

In 1969, Dr. Horacio Zalce Torres, Head of Surgery at the Oncology Pavilion and Director of the campaign against cancer, wrote: "At the beginning of the $20^{\text {th }}$ century, cancer patients were treated with radium or
Correspondence:

*Alfonso Torres-Lobatón

E-mail: drtorreslobaton44@gmail.com
Available online: 22-01-2021
Date of acceptance: 04-08-2020 DOI: 10.24875/HGMX.20000053
Rev Med Hosp Gen Mex. 2021;84(1):41-48
www.hospitalgeneral.mx

Rev Med Hosp Gen Mex. 2021;84(1):41-48
www.hospitalgeneral.mx is is apen access article under the CC BYNC-ND license (http://creativecommons.org/licenses/by-nc-nd/4.0/). 
roentgen therapy equipment acquired individually and privately long before the institutions did so. So health care was provided by radiotherapists themselves, who had acquired not only the physical agents but also the knowledge essential for their application. Surgery was performed by general surgeons or specialists from other fields. (At that time, cancerology did not exist as a specialty)"1,2.

At the General Hospital of Mexico, designed by Dr. Eduardo Liceaga, inaugurated on February 5, 1905, by President Porfirio Díaz, various surgical treatments were carried out, including cancer. At that time, it was noted that 517 surgical interventions had been performed, $95 \%$ of which corresponded to major surgery with a mortality rate of $18.3 \%$. Some of them were due to neoplastic conditions ${ }^{2,3}$

In 1962, Dr. Guillermo Montaño Islas wrote: "The first radium equipment was brought to our country in 1917, by General Alfredo Breceda, then governor of the Federal District, to treat a relative of his. Shortly afterward, at the Physiotherapy Department, Dr. Victoriano del Oro was in charge of operating the first deep therapy device"4.

Dr. Rosendo Amor, Head of Pavilion 16, an outstanding doctor who, in 1914, was appointed Head of the Gynaecology Unit, used radium and routinely performed the Wertheim-Meigs operation for the treatment of cervical cancer'4.

In 1922, under the direction of Dr. Cleofas Padilla Silva, the hospital acquired $50 \mathrm{mg}$ of radium bromide, officially starting the fight against cancer in our country. In 1927, Dr. Genaro Escalona was the second Director of the hospital, and the hospital was under the auspices of the Public Welfare Service. A second batch of radium was acquired and under the direction of Dr. José Araujo, radiotherapy was applied 1250 times to 664 patients, a third of who were suffering from cervical cancer. The Regaud method was used, similar to that used in large hospitals in Paris and consisted of small doses over long periods of time (25 mg in 168-200 h) $)^{1,3}$

Dr. Zalce, in a lecture published in $1969^{2}$, notes that at that time one or two primitive Roentgen therapy equipment were acquired that, without due knowledge of the behavior of ionizing radiation, were placed on the first floor of the Physiotherapy Hall in front of Diagnostic Radiology, above the Hydro and Mechanotherapy wards.

In 1934, Dr. Ignacio Millán, Head of the Cancerology Pavilion, wrote: "That was a forgotten and abandoned Practice, a kind of prison to which practitioners, nurses, and interns were sent when they deserved some

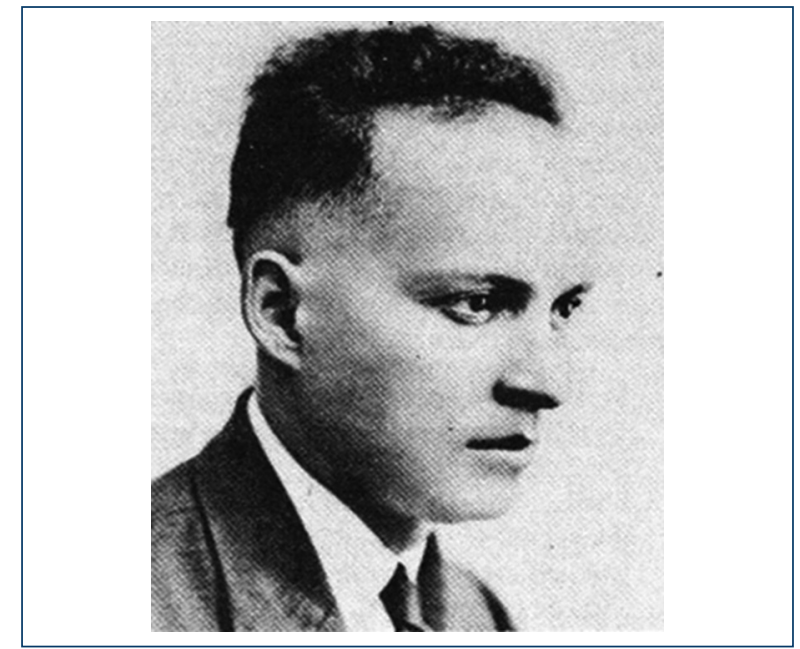

Figure 1. Dr. Francisco Millán, Head of Practice. 1937-1960.

punishment. The Radiotherapy Service was nothing more than a prelude to death where dying cancer patients were sent to"3.

In 1937, President Lázaro Cárdenas officially inaugurated the Cancerology Service located in Pavilion 13, with Dr. Ignacio Millán being its first Head (Fig. 1). Dr. Ignacio Millán had just returned from his training in New York and performed important work acquiring, thanks to his political influence, a $250 \mathrm{Kv}$ radiotherapy equipment. His academic prestige led him to be President of the $4^{\text {th }}$ International Congress of Cancerology that took place in the City of St. Louis, Missouri. An excellent photographer and organ player, he cultivated friendships with personalities such as Diego Rivera and Siqueiros.

It was not until 1940, when the Cancerology Unit of the General Hospital of the Health and Care Department was reopened in a modern building, with Dr. Aquilino Villanueva as the Hospital's Director, that the comprehensive management of cancer patients became possible in an organized environment designed for such a purpose. Initially, during the organizational phase, general surgeons who lacked clinical training and were not exclusively dedicated to tumor surgery were assigned to the Unit.

In 1942, the nascent Cancerology Service was supported by Dr. Guillermo Montaño Islas who, as a doctor in the Gastroenterology ward, was convinced by Dr. Ignacio Chávez, then Director of the Hospital, to leave that area where he predicted a slow and difficult career development, to specialize in Radiotherapy alongside the prestigious German doctor Holfelder. Dr. Ignacio 


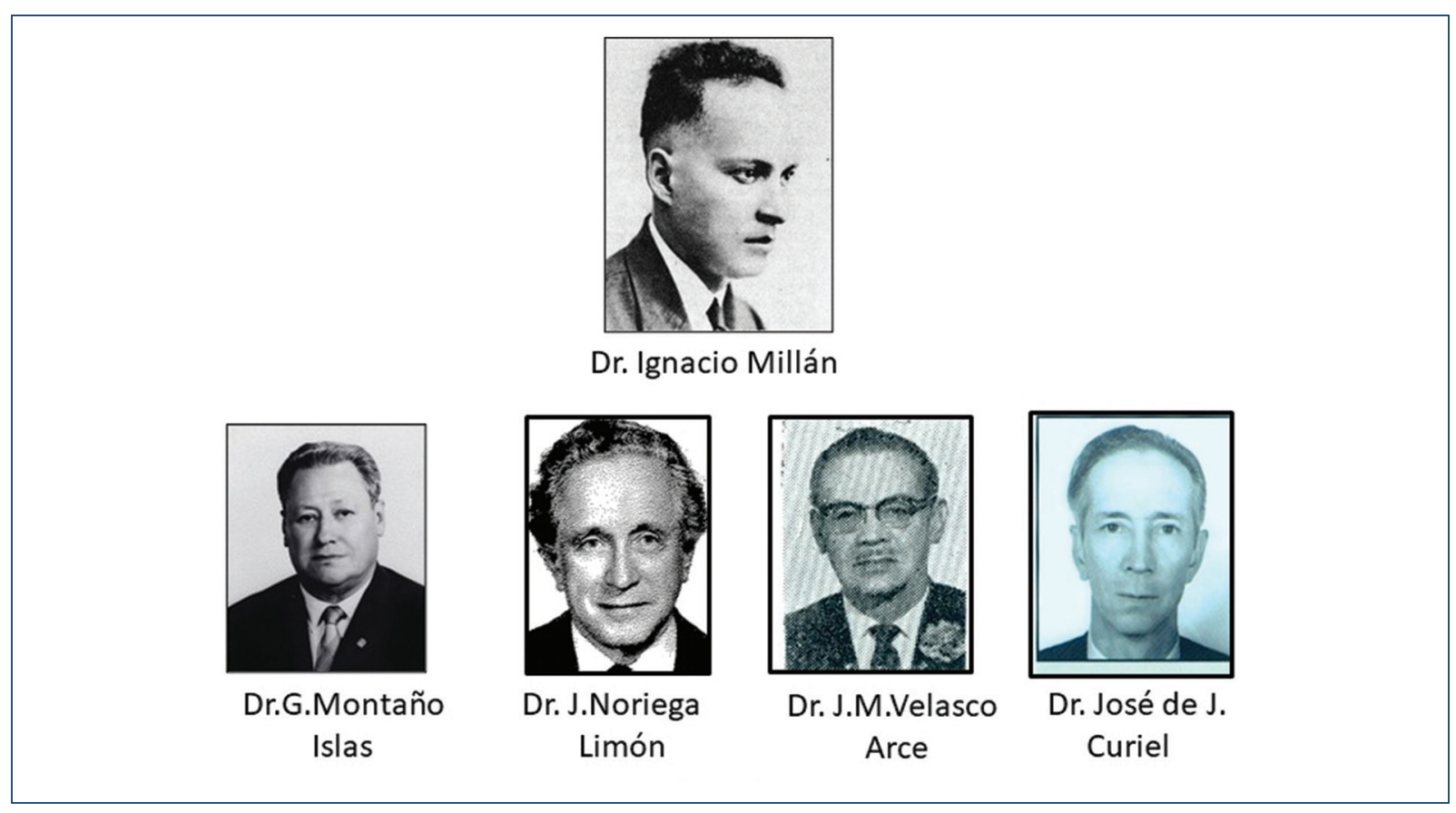

Figure 2. Specialists who made up the first centre dedicated to the diagnosis and treatment of cancer patients in Mexico.

Chavez's reasoning was based on the fact that there were no such specialists in the hospital, much less in other parts of the country ${ }^{3}$. At that time, the Pavilion was given a new floor and a building dedicated to the installation of five deep radiotherapy units and a radon plant was built, which made it possible to offer treatment to a large group of patients ${ }^{4}$.

In 1964, Dr. Zalce wrote: "With the valuable presence of Dr. José Noriega Limón, upon his return from England, who remains in charge of the Radiotherapy Department, a stage of actual collaboration and not merely peaceful coexistence between surgeons and radiotherapists begins, while the oncologist with a broad basic clinical education with a sub-specialization in surgery or radiotherapy is being insensitively developed"2. Dr. Noriega had the support of Dr. Rafael Martínez González who would later become the first Head of Radiotherapy at Sanatorium 2 of the Social Security, the forerunner of the Oncology Hospital of the National Medical Centre of the Mexican Institute of Social Security (IMSS) 2 .

In 1945, with postgraduate studies at New York's Memorial Hospital, Dr. José Manuel Velasco Arce joined Pavilion 13 as the first oncological surgeon permanently assigned to this Service and performed the first radical neck dissection under local anesthesia in Mexico.
The creation of a Pathological Anatomy laboratory, exclusive to the Service for the study of tumors, run by Dr José de Jesús Curiel, who received his training at the Pathology Service of the Memorial Cancer Centre Hospital in New York, was an addition to the group by having two radiotherapists, an oncological surgeon and a pathologist in the Pavilion. This was decisive in making Pavilion 13 the most important Care Centre in the Mexican Republic, dedicated to the diagnosis, and treatment of cancer patients ${ }^{4}$ (Fig. 2).

In 1946, Dr. Horacio Zalce, who had been admitted to the Hospital in 1934, joined Ward 13 and in 1942 he began formal postgraduate studies in Oncological Surgery at the Memorial Hospital in New York..

Dr. Zalce and Dr. Velasco Arce made up the Surgery Service and established the clinical groups on a definitive basis. These surgeons, with the support of Drs. Millán and Montaño, created the first Generation of Oncological Surgeons, as described by Dr. Zalce ${ }^{2}$, and a new School of Oncological Surgery, the first in our country.

As Head of the Head and Neck Area and later simultaneously of the Breast Area in Pavilion 13 and in the National Institute of Cancerology located in the Calle de Niños Héroes in the Doctores colony, Dr. Velasco Arce carried out a series of publications of which his work in the surgical treatment of breast cancer stands out ${ }^{5,6}$. 
In 1951, this group of doctors organized themselves to create, within the institution, a Mexican Society of Cancerology, whose name should be modified because in those years, another Organization with that name had been registered in the City of Guadalajara. They decided to name it the Mexican Society for Cancer Studies, and they became its first presidents ${ }^{7}$.

Dr. Velasco Arce was head of the service from 1971 to 1974 .

\section{Oncological surgery. Its consolidation}

The second generation of oncological surgeons with training abroad consisted of Dr. Arturo Beltrán Ortega, Dr. Rubén Oropeza, Dr. Roberto Garza Garza, Dr. Samuel Salinas Quinard, and Dr. Héctor Rodríguez Cuevas who joined the Practice, and except for Dr. Rodríguez Cuevas, they had joined other recently trained institutions where they had a brilliant performance.

Dr Héctor Rodríguez Cuevas ${ }^{8}$ studied medicine at the Universidad Nacional Autónoma de México (UNAM) Medical School. At Harvard, he studied General Surgery with the idea of doing heart surgery as his degree thesis was done at the National Institute of Cardiology on "Pulmonary Physiology" under the tutorship of Dr. Alberto Limón. With a recommendation from Dr. Ignacio Chavez, he arrived at the Massachusetts General Hospital in Boston and he studied General Surgery at Boston City Hospital. When he realized that his real interest was in large and complicated surgeries, and that at that time there was no specialty in oncological surgery in Boston, he arrived at the Memorial Hospital in New York where, by recommendation of Boston City Hospital, he started in oncological surgery.

In 1957, Dr. Héctor Rodríguez Cuevas joined the Oncology Service, and with the concepts that cancer surgery requires knowledge and discipline, he rose through the ranks in the Hospital Career of the Institution until he became Chief of Surgery in 1973 and later Chief of the Oncology Service in 1982 (Fig. 3).

Dr. Rodriguez Cuevas consolidated the specialty and formed a surgical school that catered for many institutions in the country. In the academic field, his publications in the journal Cancer of the United States: New Surgical Approach to Nasopharyngeal Angiofibroma ${ }^{9}$, and the diagnostic and therapeutic approach to cervical paragangliomas in patients from the highlands of Mexico City and the State of Mexico, stand out ${ }^{10}$.

During his term of office, in 1987, he created the Society of Residents and Graduates of the Service, of which he was president for life. In the same year, the

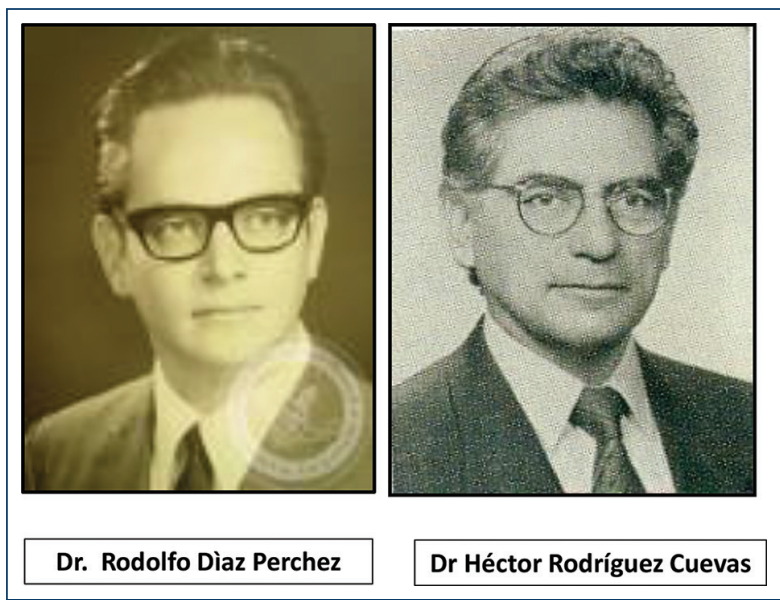

Figure 3. Masters who consolidated and designed the radiation oncology and oncological surgery.

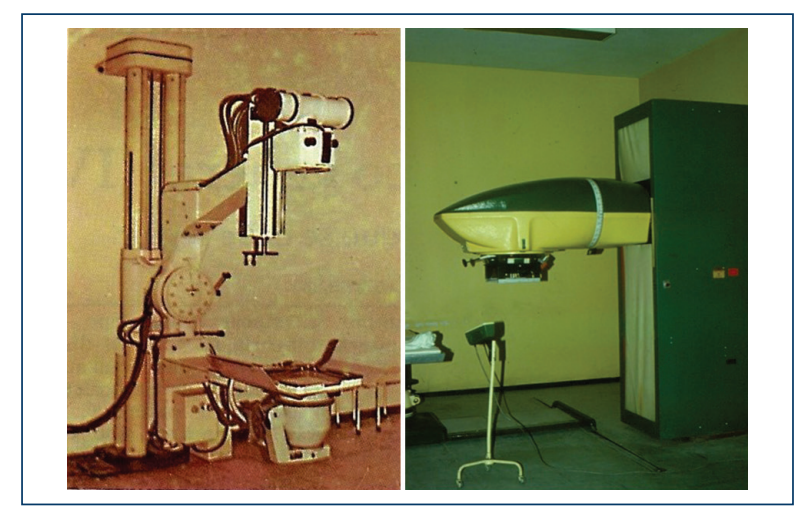

Figure 4. Old simulator and old cesium pump.

heads of the four surgical units were created through competitive examinations: the mixed tumors unit, headed by Dr. José Mario de la Garza Navarro; the head and neck unit, headed by Dr. Javier García Estrada; the gynecological tumors unit, headed by the author of the article; and the breast tumors unit, headed by Dr. José Antonio Serrano y Migallón (Fig. 4).

Twelve of his students made up the third generation of oncological surgeons, in addition to those mentioned above: Dr. Dimas Hernández Aten, Dr. Basilio Ramírez Guzmán, Dr. Isaías Cervantes Zúñiga, Dr. Eduardo Arana Rivera, Dr. Hernando Miranda Hernández, Dr. Francisco Sandoval Guerrero, Dr. Edgar Román Basaure, and Dr. Luis R. Días Rodríguez. Four of whom are still working there.

In close relationship with the Surgical Units, the Department of Oral and Maxillofacial Prosthesis was formed in the 1970s, under the direction of Dr. Enrique 


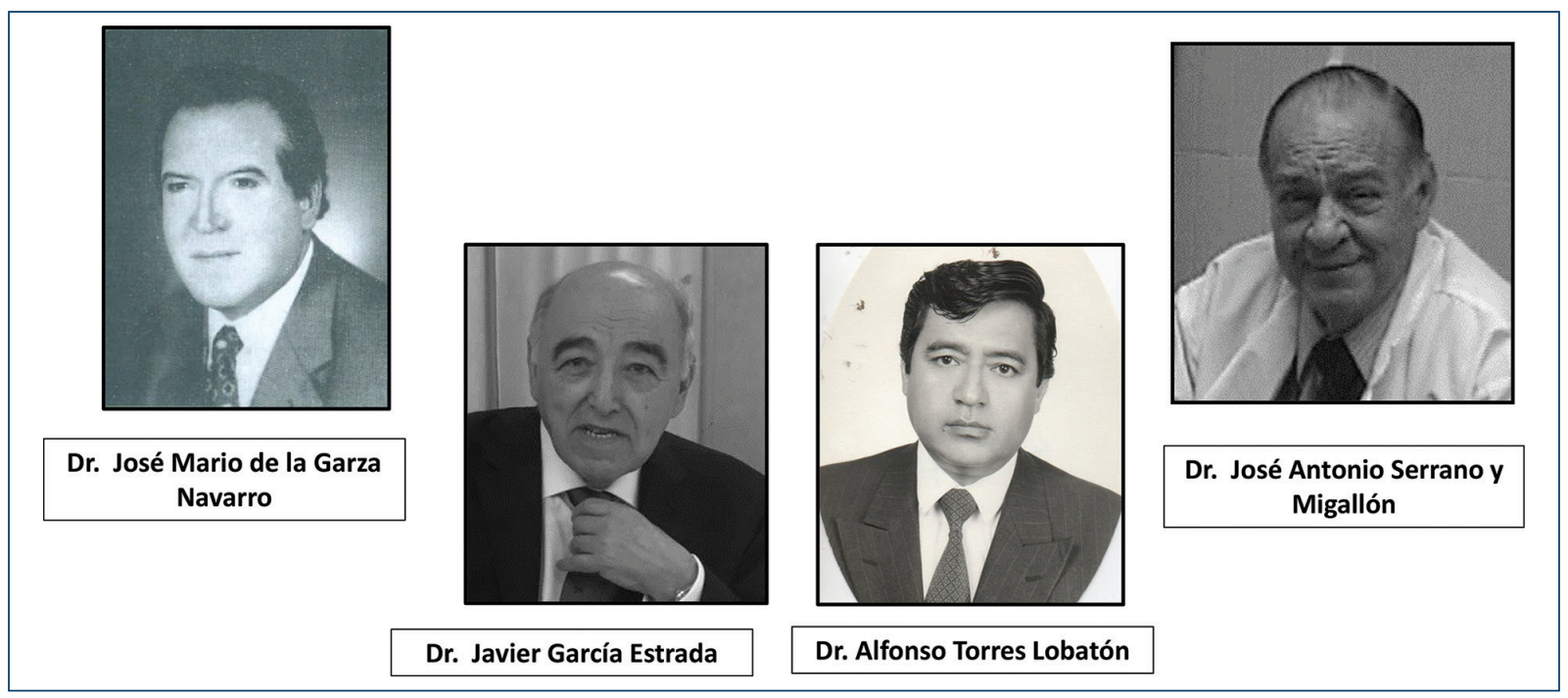

Figure 5. They become heads of the surgical units by practical exams in 1987.

Echevarría y Pérez who created a school for the development of prostheses for the Head and Neck and Mixed Tumor Units. This school is still in operation.

\section{Evolution of radiotherapy}

In 1956, Dr. Montaño became President of the National Academy of Medicine and in 1960, Head of the Oncology Service. He participated in the planning of the Oncology Hospital of what would be the Medical Centre of the Secretary of Health which was ceded to the IMSS. In 1961, he created the Specialization Course in Oncology, with the recognition of the Division of Higher Studies of the UNAM, with which it was no longer necessary to travel abroad to obtain knowledge in the management of neoplasms.

Once Dr. José Noriega Limón left the Service to found a nascent National Institute of Cancerology, with the support of Dr. Rodolfo Díaz Perches, Pavilion 13 had a new restructuring ${ }^{4}$.

Dr. Rodolfo Díaz Perches, a graduate of the UNAM School of Medicine, completed his undergraduate internship at the General Hospital in 1953. His interest in ionizing radiation arose when he had the opportunity to work at that time in the laboratory of the French Hospital, next to the General Hospital, where he was suggested to write his thesis on the use of artificial radio-isotopes in medicine. His interest led him to receive training in Radiotherapy and Radioisotopes at Columbia University and Mount Sinai Hospital in New York, to complete it later through a scholarship at Middlessex Hospital in London ${ }^{11}$ (Fig. 3).
At the end of 1957, he joined Pavilion 13 and supported Dr. Guillermo Montaño in restructuring the Radiotherapy Service, taking care to achieve reasonable calibration of its equipment and correct planning. In this respect, Dr. Díaz Perches wrote: "The equipment we had was so old that it took a long time because its performance was very low; moreover, it did not even set the time, so an alarm clock was used to set the treatment time"11. Figure 5 shows calibration equipment from this period and a caesium pump (Fig. 5).

In the seventies, the radiotherapy service was formed by the following doctors who had been trained in the Institution: Drs. Alfonso Anguiano Razo, Julio Molina Esquivel, Dr. César Alcalá, Dr. Lourdes Flores López, and Dr. Humberto García González, who would become the Head of the Service. Furthermore, Dr. Ma. Cleofas Gallardo trained in a French institution of Radio Oncology. In 1975, Dr. Díaz Perchez became the head of the Service and in 1982, the General Management of the Hospital.

Table 1 shows the frequency of malignant neoplasms found in autopsies at that time ${ }^{12}$.

\section{Evolution of medical oncology}

Due to the scarcity of antineoplastic drugs, this specialty has been developed long after radiotherapy and oncological surgery ${ }^{13}$. However, the role of female sex hormones in the development of advanced breast cancer has been demonstrated since the $1950 \mathrm{~s}^{14}$. In 1951 , Dr. Montaño created and was in charge of a laboratory 
specialized in the study of hormones, whose working group had the aim of investigating the factors and hormonal relationships of breast and cervical cancers.

In 1960, Dr. Joaquín Rivadeneyra H., Endocrinologist at the General Hospital and member of the "Cancer and Hormones" Research Group in Ward 13, carried out a study of the value of oophorectomy in 85 cases of advanced breast carcinoma ${ }^{14}$. At that time, Pavilion 13 already had an incipient Immunology laboratory run by Drs Héctor Munguía and Dr Ester Franco G.

The first specialist with formal education in medical oncology who worked in the Service was Dr. Irma Nora Hidalgo who, with training abroad in the 1960s and with the collaboration of Dr. Graciela Flores López, formally began to care for oncology patients, supported by a small bank of medicines obtained by the Hospital Management and through donations acquired by Drs. Montaño and Diaz Perches.

At the end of the 1960s, Dr. Raquel Gerson Cwilich joined the service as an intern, conducting a study on the epidemiology of patients attending the service at that time. This experience led her to study medical oncology abroad at universities such as Northwestern Chicago, Illinois, Tufs, and Harvard, before returning to Mexico to put into practice the knowledge she had acquired abroad in the Pavilion where her professional career began.

Dr. Hidalgo decided to continue his professional practice in the city of Tampico Tamaulipas where he still lives and with the collaboration of Dr. Graciela Flores, Dr. Gerson consolidated in the 1970s the Medical Oncology Unit, which would have specialists trained such as Dr. Jazmin Figueroa Badillo and Dr. Miguel Lazaro Leon.

\section{The oncology service its evolution toward the present}

In 1990, the author took over as Head of the Service and during his term of office, the Oncology Department of the Hospital progressed toward modernization. A modern linear accelerator was acquired (Fig. 6); a bank of oncological drugs was created, and with the support of Dr. Jesús Kumate Rodríguez, Secretary of Health, the National Centre of Dysplasia Clinics was set up in the practice for the diagnosis and management of cervical cancer precursor lesions, under the responsibility of Dr. Fernando Cruz Talonia, an oncological surgeon who had been an intern of the Practice. The Department of Oncological Psychology was also created, headed by Dr. María del Carmen Calderón Benavides.
Table 1. Frequency of Malignant Tumors in 1586 autopsies. General Hospital of Mexico

\begin{tabular}{|l|l|c|c|}
\hline Range & Site & Number & Percentage \\
\hline 1 & Cervix & 320 & 20.7 \\
\hline 2 & Lymphomas & 144 & 9.08 \\
\hline 3 & Lung & 114 & 7.19 \\
\hline 4 & Stomach & 112 & 7.06 \\
\hline 5 & Breast & 96 & 6.05 \\
\hline 6 & CNS & 94 & 5.93 \\
\hline 7 & Soft tissues & 81 & 5.11 \\
\hline 8 & Gallbladder & 62 & 3.91 \\
\hline 9 & Bladder & 48 & 3.03 \\
\hline 10 & Thyroid & 46 & 2.9 \\
\hline 11 & Others & 469 & 29.57 \\
\hline & Total: & 1586 & 100 \\
\hline
\end{tabular}

Adapted from Brandt $\mathrm{H}$, et al. ${ }^{12}$

In the teaching field, the specialties of oncological surgery, radio-oncology, and medical oncology were recognized at university level. In the academic field, scientific production continued through publications related to the management of the most important pathologies in our country ${ }^{15-17}$.

In 2004, Dr. Torres Lobatón, Dr. José Antonio Serrano Magallón, and Dr. Eduardo Arana Rivera succeeded in modernizing the radiotherapy unit with a new building and the acquisition of three linear accelerators and equipment for the application of interstitial radiotherapy.

At this time, the Hospital adheres to the Catastrophic Expenses program, where cervical cancer patients receive their treatment free of charge, gradually adding to this benefit other ailments such as breast cancer, testicular cancer, prostate cancer, and gynecological cancers of the ovary and endometrium.

During his term as head of the Service, Dr. Eduardo Arana became President of the Mexican Society of Oncology and created the official journal of the Society: the Gaceta Mexicana de Oncología. In 2007, the Postgraduate Division of the Faculty of Medicine of the UNAM recognized the specialty of gynecological oncology created by the author within the oncology service.

Finally, in November 2011, when Dr. Edgar Román Basaure was in charge of the Service, the President of the Republic, Felipe Calderón Hinojosa, inaugurated the Haemato-Oncology Service Tower, the first of the towers that the institution currently has. 


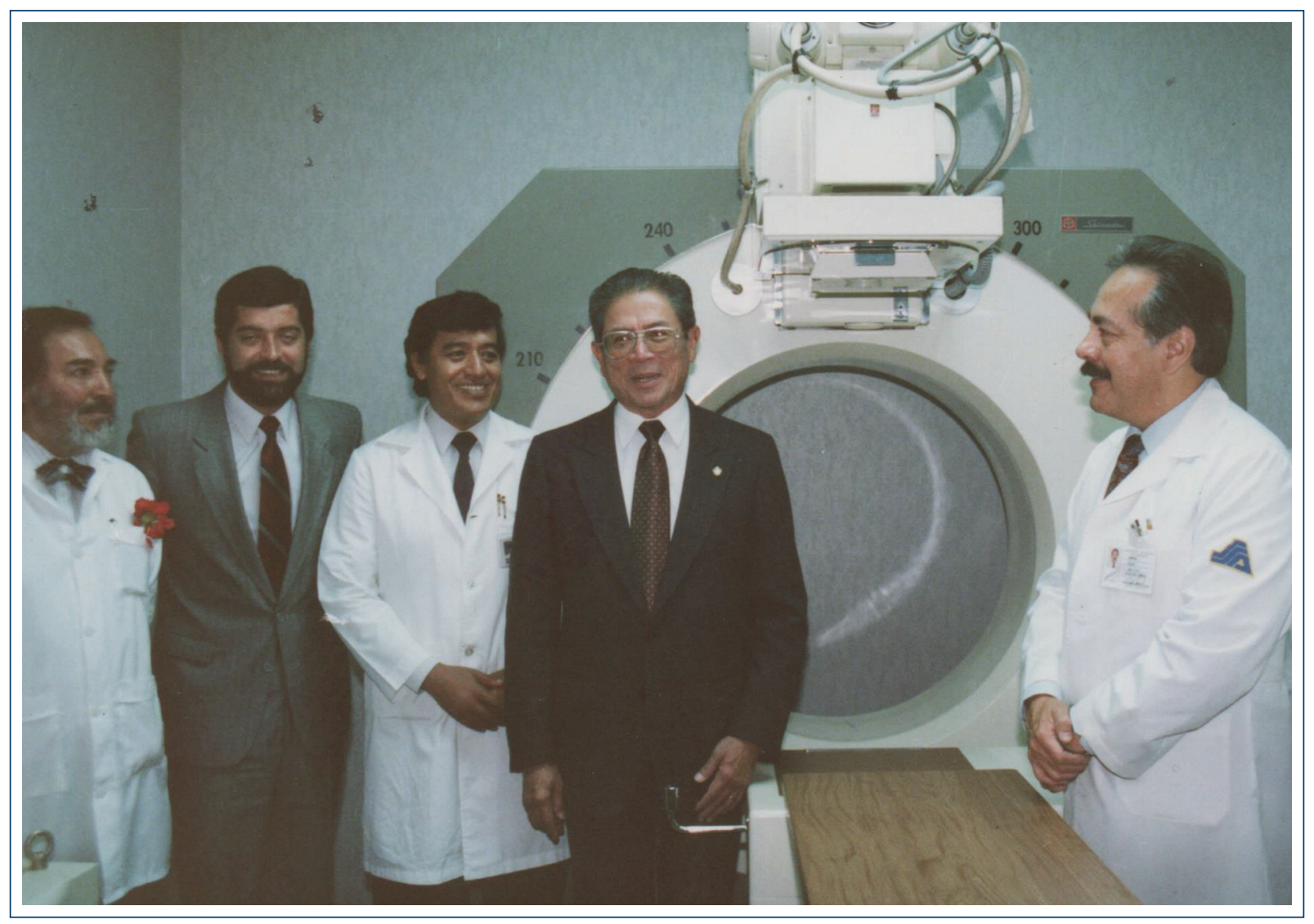

Figure 6. Inauguration in 1993 of the second Linear Accelerator acquired by the Institution (From left to right: Dr. Humberto García G, Head of Radiotherapy; Dr. Juan Ramón de la Fuente, Sub-Secretary of Health; Dr. Alfonso Torres L, Head of Practice; Dr. Jesús Kumate R. Secretary of Health; and Dr. José Luis Ramírez A. Director of the Hospital).

\section{Conclusions}

The General Hospital of Mexico is the cornerstone of oncology in our country

In 1937, the oncology service was opened in Pavilion 13 with the radiotherapy equipment available at that time, under the direction of Dr. Ignacio Millán.

It was in the 1940s that comprehensive care of neoplasms was formally established when Dr. Guillermo Montaño Islas joined the practice as the founder of radiotherapy in our country, Dr. José Manuel Velasco Arce, acting as the first oncological surgeon and Dr. José de Jesús Curiel as a pathologist.

Dr. José Manuel Velasco Arce and Dr. Horacio Zalce Torres, trained abroad, were the first generation of oncological surgeons in the country.

A second generation of oncological surgeons with training abroad consisted of Doctors Arturo Beltrán Ortega, Rubén Oropeza, Roberto Garza Garza, Samuel Salinas Quinard, and Dr. Héctor Rodríguez Cuevas who consolidated the School of Oncological Surgery of the Institution.

Doctors Guillermo Montaño Islas, José Noriega Limón, and Rodolfo Díaz Perchez, developed the professional attention of the radiotherapy in the Institution. Dr. Montaño, created the specialty of Oncology in Mexico.

Doctors Irma Nora Hidalgo, Graciela Flores López, and Raquel Gerson Cwilich, made up the first generation of medical oncologists to work with the service.

The practice currently offers five specialties: Oncological Surgery, Gynaecological Oncology, Medical Oncology, Radio-Oncology, and Oral and Maxillofacial Prosthesis.

When the Hemato-Oncology Tower was inaugurated in 2011, the service had modern facilities, making it one of the most important in the country.

\section{Conflicts of interest}

The author expresses has no conflict of interest in relation to this manuscript. 


\section{Funding}

The author declares this work that not requires any funding or sponsorship.

\section{Ethical disclosures}

Protection of human and animal subjects. The authors declare that no experiments were performed on humans or animals for this study.

Confidentiality of data. The authors declare that they have followed the protocols of their work center on the publication of patient data.

Right to privacy and informed consent. The authors declare that no patient data appear in this article.

\section{References}

1. Horacio Z. Cirugía oncológica: su razón de ser y su desarrollo en México. Cir Cir. 1965;33:299-306.

2. Horacio Z. El oncólogo dentro de la profesión médica mexicana. Rev Med Hosp Gral Méx. 1969;32:383-93.

3. de Kury MD, Treviño CV. Historia del Hospital General de México 19052010. $2^{\text {nd }}$ ed. Coord. Edit. Gráfica, Creatividad y Diseño. Ciudad de México, México. 2010. p. 195, 200, 217, 227-8.
4. Gmo Ml. El Hospital General en la lucha contra el Cáncer en México. Rev Med Hosp Gral Méx. 1962;25:161-8.

5. Arce JM, Espinosa R, Garza GR, Mayer PJ, Millán LP, Millán PF, et al. Cirugía ampliada en cáncer de mama. Revisión de 196 casos de mastectomía super radical. Cir Cir. 1965;33:1-29.

6. Arce JM. La mastectomía super radical en el cáncer mamario. Revisión de 159 casos. Rev Med Hosp Gral Méx. 1967;30:623-46.

7. Historia de la Sociedad Mexicana de Oncología 1951-2004. Médicos de México (Edición Especial). Alianza 3 Grupo Editorial, Mexico City, Mexico; 2004. p. 16-27.

8. Cuevas HR. Entrevista. Actualidades e Innovaciones en Oncología; 2011.

9. Rodríguez $\mathrm{H}$. A new surgical approach to nasopharyngeal angiofibroma. Cancer 1966;19:458-60.

10. Cuevas HR, Lau I, Rodríguez $\mathrm{OH}$. High-altitud paragangliomas diagnostic and therapeutic considerations. Cancer 1986;57:672-6.

11. Rodolfo DP. La radioterapia en el hospital general de México en: Historia de la sociedad mexicana de oncología 1951-2004. Méd Méx 2004;3:16-55.

12. Brandt $\mathrm{H}$, Altamirano BM, Albores SJ. Frecuencia de cáncer en el Hospital General de México. Rev Med Hosp Gral Méx. 1968;31:267-78.

13. De la Garza Salazar J. Un relato histórico de la Oncología Médica en México. Mexico: Editores de Textos Mexicanos; 2011. p. 63-82.

14. Rivadeneyra JH, Velazco AJ, Montaño IG, Munguía H, Franco GE. EI valor de la ooforectomia en el tratamiento del cáncer mamario avanzado. Análisis crítico de 85 casos. Rev Med Hosp Gral Méx. 1960;23:415-20

15. Torres LA, Lara GC, Oliva PJ, Torres RA, Román BE, Morales PM, et al. Laparotomía Exploradora por Cáncer Cervicouterino Persistente o Recurrente a Radiación. Vol. 10. Experiencia con 931 Pacientes. GAMO; 2011. p. 335-42.

16. Miranda HH, Mociños MR, De la Peña JV, Sánchez FE, Lázaro LM. Colocación de catéter Central transoperatorio en pacientes con cáncer de mama que requieren de quimioterapia adyuvante. Rev Med Hosp Gral Méx. 2003;66:126-30.

17. Torres LA, Barra MR, Jiménez AP, Portillo RJ, Suárez JC, Morgan OF. Obesity and endometrial cancer: the impacto of a public health problem. Ginecol Obstet Mex. 2020;88(09):569-574. 